University of Nebraska - Lincoln

DigitalCommons@University of Nebraska - Lincoln

Publications, Agencies and Staff of the U.S.

Department of Commerce

U.S. Department of Commerce

$12-1-2000$

\title{
Further Scrutiny of Scientific Whaling
}

Robert L. Brownell Jr.

Southwest Fisheries Science Center, rlbcetacea@aol.com

Michael F. Tillman

Southwest Fisheries Science Center, mftillman@mac.com

Giuseppe Notarbartolo di Sciara

Istituto Centrale per la Ricerca Applicata al Mare, Via di Casalotti 300, 00166 Roma, Italia

Per Berggren

Stockholm University

Andrew J. Read

Duke University, aread@duke.edu

Follow this and additional works at: https://digitalcommons.unl.edu/usdeptcommercepub

Part of the Environmental Sciences Commons

Brownell, Robert L. Jr.; Tillman, Michael F.; Notarbartolo di Sciara, Giuseppe; Berggren, Per; and Read, Andrew J., "Further Scrutiny of Scientific Whaling" (2000). Publications, Agencies and Staff of the U.S. Department of Commerce. 135.

https://digitalcommons.unl.edu/usdeptcommercepub/135

This Article is brought to you for free and open access by the U.S. Department of Commerce at DigitalCommons@University of Nebraska - Lincoln. It has been accepted for inclusion in Publications, Agencies and Staff of the U.S. Department of Commerce by an authorized administrator of DigitalCommons@University of Nebraska - Lincoln. 


\section{SCIENCE'S COMPASS}

\section{Further Scrutiny of Scientific Whaling}

Normile reports on Japan's expanded scientific whaling program and notes that "Canada, the United States, the Soviet Union, South Africa, and Japan were among several countries that [conducted scientific whaling] before 1982 [the year the IWC passed the worldwide commercial moratorium on whaling], but in recent years Japan has stood alone." Although true, this statement omits three equally important points.

First, Iceland and Norway exploited the scientific whaling provision allowed by the IWC. Between 1986 and 1994 both countries killed 651 whales in the name of science (1), and between 1987 and 1991 Japan imported 4146 metric tons of whale meat, including 4036 tons of research whale meat from Iceland (2). More meat might have been exported, but in 1986 the IWC passed a resolution on scientific whaling that recommended that "the meat as well as the other products should be utilised primarily for local consumption." Iceland withdrew from the IWC in 1992, and Norway reinitiated commercial whaling for minke whales in 1993 under its objection to the IWC commercial moratorium.

Second, the number of whales killed in scientific whaling programs before the commercial moratorium was at most in the low hundreds, and these programs were of limited duration. The Japanese started research whaling for Antarctic minke whales in the austral summer of $1987 / 88$, which is when the commercial moratorium began. They have killed 4595 minke whales so far (1) and are about to start whaling for the 14th year (the first 2 years were called a "feasibility study"). The Antarctic minke whale research program is scheduled to continue until the 2003/04 season. In the North Pacific, the Japanese started research whaling on minkes in 1994 and have killed more than 500 whales (1). Since the $1987 / 88$ season, Japan's research whaling program has taken 5181 whales, about 2.4 times as many as were taken between 1949 and 1987 by all other countries combined.

Third, the IWC established a Southern Ocean Sanctuary in 1994 (Japan was the only member nation that voted against it), but since then Japan has continued to take all of its annual catch of Antarctic minke whales within the sanctuary boundary, despite repeated requests by IWC that it not hunt there.

Robert L. Brownell Jr.

Michael F. Tillman

Southwest Fisheries Science Center, Post Office 271, La Jolla, CA 92038, USA. E-mail: robert. brownell@noaa.gov and michael.tillman@ noaa.gov

Giuseppe Notarbartolo di Sciara Istituto Centrale per la Ricerca Applicata al Mare, Via di Casalotti 300, 00166 Roma, Italia. E-mail: disciara@tin.it Department of Zoology, Stockholm University, S10691 Stockholm, Sweden. E-mail: per.berggren@ zoologi.su.se

Andrew J. Read Nicholas School of the Environment, Duke University Marine Laboratory, Beaufort, NC 28516, USA. E-mail: aread@mail.duke.edu

References and Notes

1. Data available from the Secretariat of the International Whaling Commission, Station Road, Histon, Cambridge CB4 4NP, UK.

2. Japanese import statistics, Statistics and Information Department, Ministry of Agriculture, Forestry and Fisheries, Tokyo, Government of Japan, and Statistical Bureau of Iceland, Foreign Trade, Reykjavik, Iceland. 